\title{
Il contributo della rappresentazione alla percezione dell'architettura. Orientamento, connessioni spaziali e accessibilità
}

\author{
Cristina Càndito \\ Alessandro Meloni
}

Abstract

Il campo di indagine del presente contributo comprende gli elementi legati all'orientamento spaziale e il loro recepimento attraverso la percezione, coinvolgendo il concetto di rappresentazione mentale con implicazioni nell'ambito del wayfinding. I soggetti studiati sono gli interni architettonici, sia nelle loro caratteristiche ideali, che favoriscono o complicano la funzione dell'orientamento, sia attraverso architetture reali, capaci di illustrare propriamente alcune di queste particolarità. Abbiamo impiegato studi e ricerche compiute nell'ambito dell'architettura e delle scienze neurocognitive applicando metodologie proprie della rappresentazione, che permettono di simulare situazioni spaziali o di evidenziare alcuni aspetti di architetture esistenti. In particolare, abbiamo osservato come le caratteristiche descritte possano essere classificate secondo due tipologie di modalità per la connessione - o la riduzione delle distanze - tra spazio e fruitore: fisica e visiva. Nel corso dello studio si è rilevato come l'immagine mentale, che coinvolge diversi aspetti neurocognitivi, può essere favorita anche da fattori fondati non esclusivamente sulla visione. Tali elementi risultano utili anche per rendere la percezione spaziale inclusiva nei confronti delle persone con disabilità sensoriali, con un'attenzione all'accessibilità non più limitata ai solo aspetti funzionali dell'architettura.

\section{Parole chiave}

percezione, orientamento, wayfinding, accessibilità, multisensorialità.

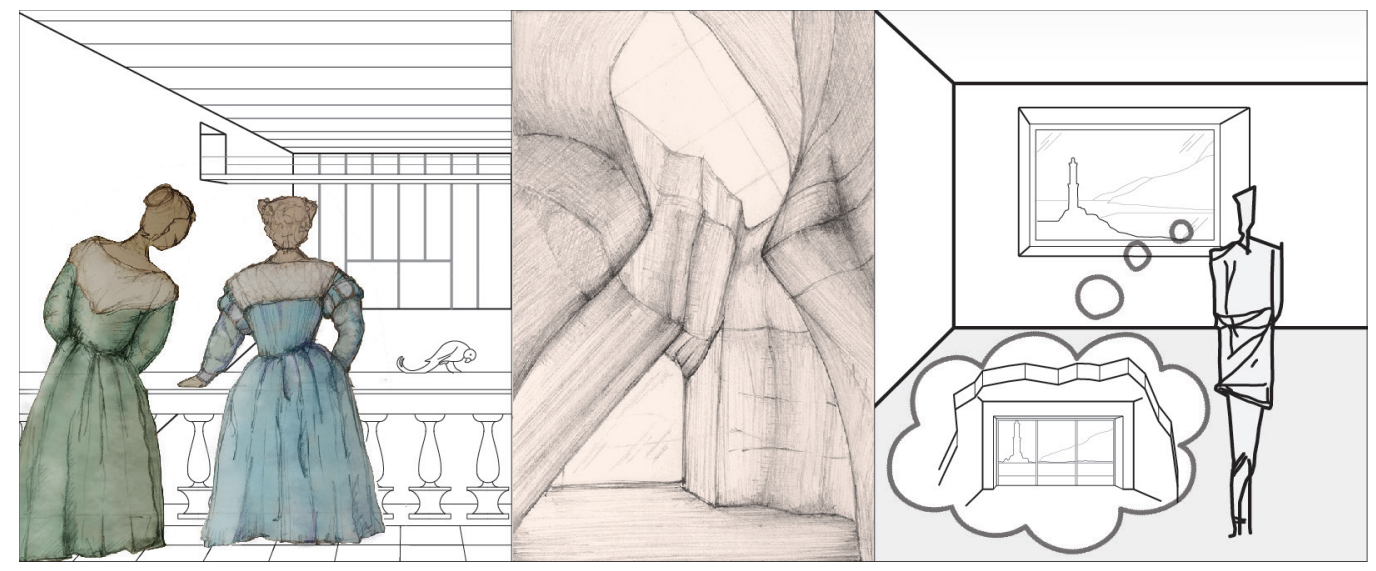




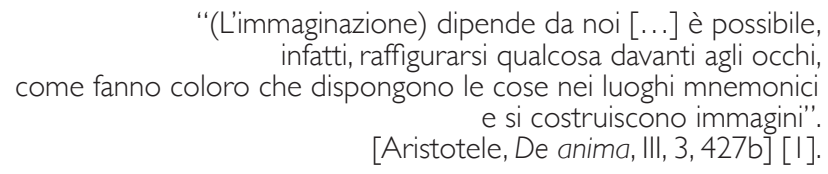

\section{Orientamento nello spazio e rappresentazione}

La conoscenza di una configurazione spaziale si fonda sulla sua rappresentazione mentale: le tracce raccolte attraverso i sensi e la loro percezione permettono la generazione di mappe utili per l'orientamento all'interno degli edifici, oltre a suscitare episodi capaci di condurre a letture articolate e coinvolgenti.

II presente contributo indaga alcune caratteristiche dell'impatto percettivo generato all'interno dell'architettura, concentrandosi su elementi legati all'orientamento analizzati attraverso i metodi delle discipline del disegno. II 'senso di direzione' trova una sintesi nella formulazione di una 'mappa cognitiva' nella zona dell'ippocampo, dopo aver coinvolto diverse parti del cervello [Berdik 2009] poiché è un'abilità che interessa l'ambiente, con la sua percezione e la sua memoria, ma anche il corpo, con la sua posizione e i suoi movimenti. Per questo motivo abbiamo considerato le ricerche sul wayfinding [Lynch 1960; Golledge, Stimson 1997], anche in ambito Space Syntax (insieme di teorie, metodi e strumenti mirati alla descrizione dei fenomeni di relazione tra spazio e società) [Hillier 1996 (ediz. 2007)] e alcuni studi riguardanti specificatamente l'orientamento all'interno degli edifici complessi, integranti l'ambito neurocognitivo e quello architettonico [Dalton Conroy et al. 20 I5]. I metodi di indagine propri della rappresentazione ci hanno suggerito l'utilità di tradurre in immagini alcune caratteristiche descritte dalle precedenti ricerche, per scoprire nuove implicazioni e individuare una loro funzionale classificazione secondo due tipologie di connessione - o di riduzione delle distanze - tra spazio e fruitore: quelle fisiche e quelle che invece si basano su elementi visivi. Tali caratteristiche sono state analizzate anche attraverso architetture reali, che non sono considerate quali casi studio ma come esempi per impostare un dialogo critico con altre proprietà architettoniche e per estendere le considerazioni alle percezioni non visive [Mallgrave 20I3; Robinson, Pallasmaa 20I5]. In questo campo, risulta proficuo il dialogo con esperienze che approfondiscono la conoscenza dello spazio in presenza di disabilità visive [Papadopoulos 20 17]. II presente studio, infatti, fa parte di una più ampia ricerca circa l'accessibilità, intesa non solo come impiego funzionale dell'architettura, bensì come promozione dell'inclusione e del contemporaneo implemento dell'espressività delle caratteristiche spaziali.
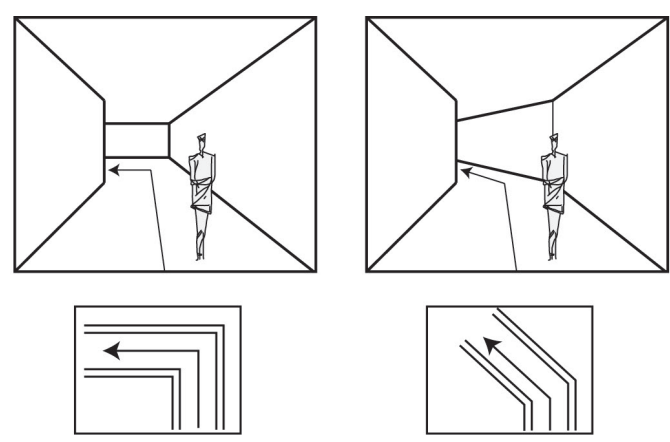
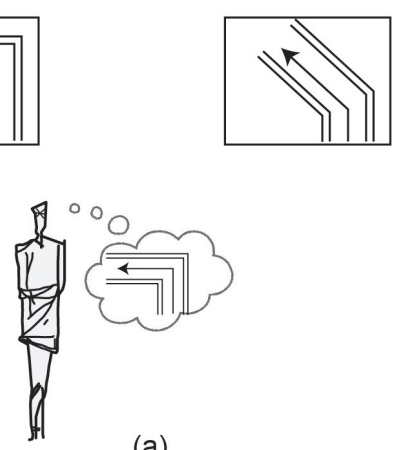

(a)
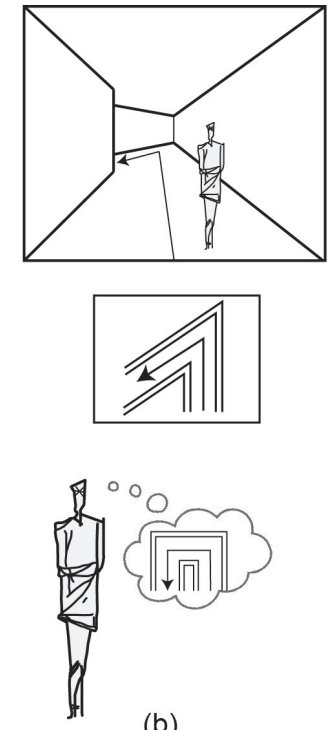

(b) 


\section{Connessioni spaziali fisiche tra orientamento e percezione}

Durante il processo di esplorazione dello spazio, la sua ricostruzione mentale ha un ruolo rilevante in quanto permette di estrapolarne i principali elementi utili per l'orientamento. I cambi di direzione che si verificano all'interno di un edificio, ad esempio, sono capaci di influenzare i comportamenti e la percezione dello spazio percorso. Tendenzialmente l'utente è più incline a intraprendere percorsi rettilinei [2] e con curvature con angoli di svolta inferiori o uguali ai $90^{\circ}$ (fig. I a); una svolta superiore, infatti, sembrerebbe ricondurre alla provenienza, generando così disorientamento (fig. Ib) [Dalton Conroy et al. 20 I5, pp. I8, 19]. Questo processo di schematizzazione del percorso favorisce il ricordo e facilita la possibilità di ripercorrere lo spazio: un'esigenza innata riconducibile all'istinto di sopravvivenza [Dalton Conroy 2003]. Si possono evidenziare gli atteggiamenti che si verificano soprattutto negli edifici multipiano che per caratteristiche spaziali e distributive risultano più complessi; gli utenti che esplorano questi ambienti presuppongono che gli elementi principali di ogni piano siano ugualmente disposti [Dalton Conroy et al. 2015, p. 19].

(a)

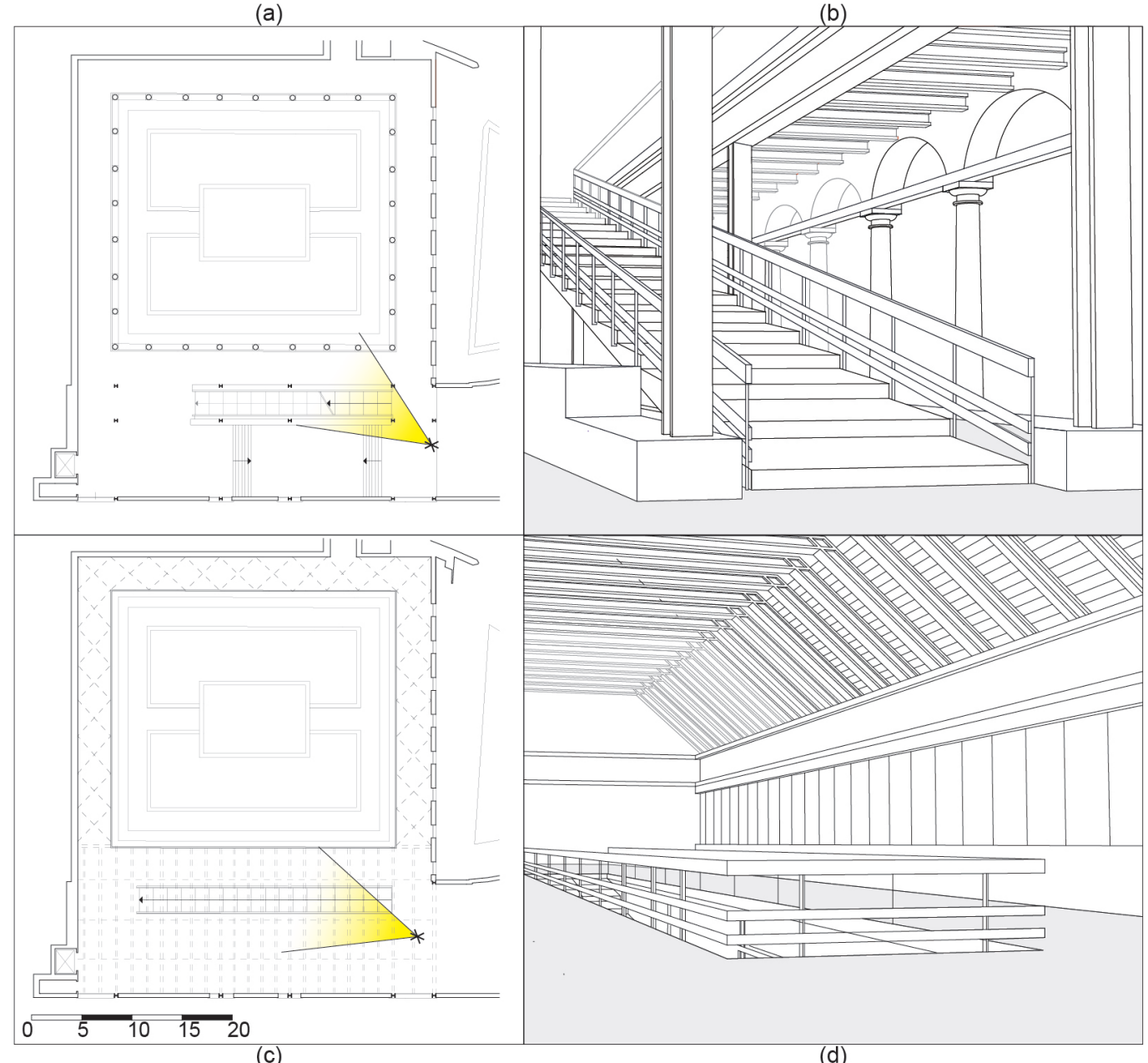

Fig. 2. Museo di Sant'Agostino, Genova; (a) Planimetria piano primo;

(b) Visione del piano primo dove si evidenziano le arcate che delimitano il chiostro settecentesco (c) Planimetria piano secondo; (d) Visione del piano secondo che evidenzia la serie continua di finestre. (c)

(d)

Tra i molti esempi individuabili, il Museo di Sant'Agostino a Genova (Franco Albini, 19631979) [3] enfatizza questo aspetto attraverso la centrale rampa di scala, che si ripete a ogni piano diventando il punto di riferimento per la navigazione all'interno dell'edificio (fig. 2a, c). II modello è la scalinata 'alla genovese', in cui la profondità della pedata in rapporto a un'alzata ridotta permette di assimilarla a una rampa inclinata, che induce a una lenta salita verso 
Fig. 3. Museo di Sant'Agostino, Genova:

(a) Planimetria piano

primo: in rosso, la strut-

tura in acciaio del solaio

(b) Sezione A-A', dove vengono evidenziate le catene delle capriate di copertura; (c) Vista interna: in rosso, le travature della struttura.
Fig. 4. Museo Davide Chiossone, Genova. (a) Sezione che evidenzia la disposizione dei piani; (b) (c) Spazio iel piani: (b), (c) Spazio interno (foto di Paolo Monti, 971 ; < https://commons. wikimedia.org/> (consultato il 20 febbraio 2021).

Fig. 5. Simmons Hall, Cambridge, Massachusetts. (a) Vista esterna <https:// commons.wikimedia. org/> (consultao il 20 febbraio 202I);

(b) Sezione A-A'

(c) Pianta piano settimo.

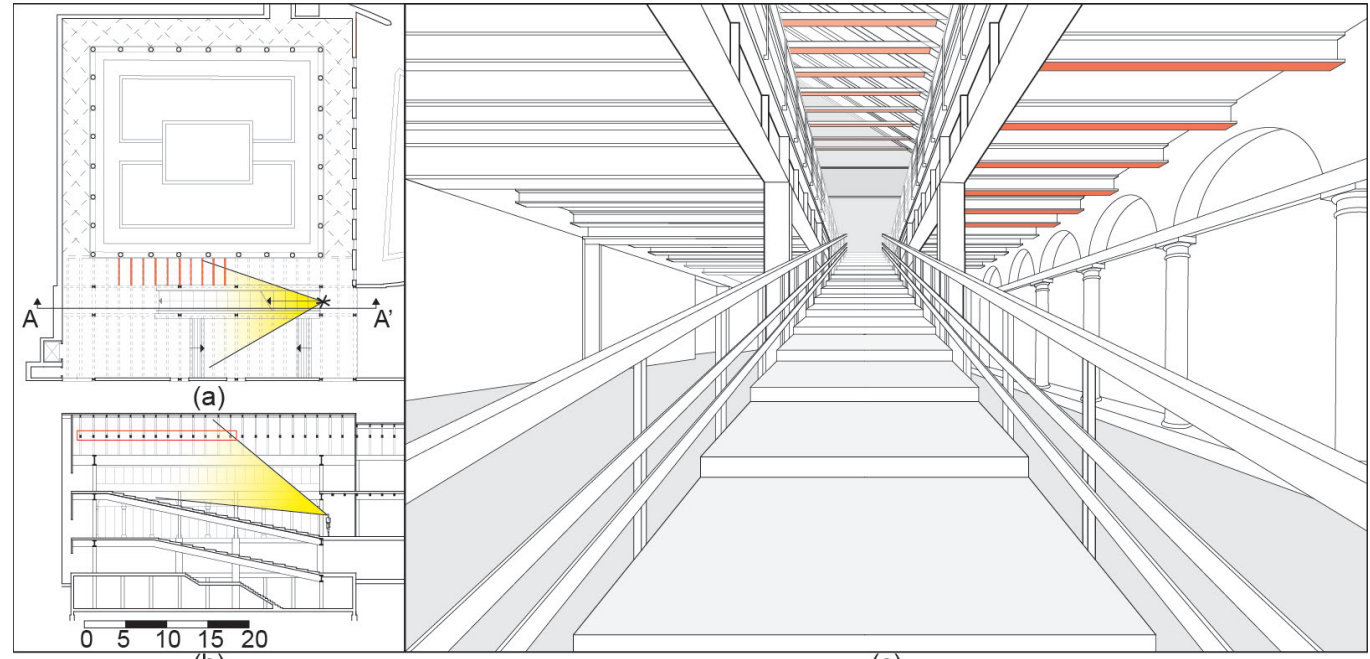

(b)

(c)

il piano superiore, ideale per cogliere più a fondo la qualità spaziale. Inoltre, gli elementi architettonici che definiscono l'affaccio sul chiostro settecentesco variano a ogni livello, facilitando il riconoscimento dei diversi piani (fig. 2b, d). La ripetizione delle travi in acciaio a vista diventa un elemento che si ritrova anche all'ultimo piano, con le catene delle capriate (fig. 3): una ripetizione che può essere ritenuta 'pletorica' [Bucci, Rossari 2005, p. 58] ma che evidenzia la scansione spaziale utile per l'orientamento interno.

Un'analoga percezione si può ritrovare anche all'interno del Museo di Arte Orientale Davide Chiossone di Genova (Mario Labò, 1948-197I) [4]. Si tratta di un'architettura definita da elementi semplici che nascondono complessità legate alla geometria e al sistema distributivo. Lo spazio espositivo è articolato in cinque livelli sfalsati tra loro che si dispongono a ridosso dei lati maggiori dell'edificio e si affacciano internamente su uno spazio a tutta altezza che connette visivamente l'intero volume. L'aspetto caratterizzante è determinato dalla distribuzione: le scale in acciaio e legno sono disposte alle estremità dei livelli a eccezione dell'ultimo, dove la scala ruota di $90^{\circ}$ per consentire la definizione di un percorso ciclico e intuitivo. Si tratta di una rivisitazione del concetto del "museo continuo e a crescita illimitata" elaborato
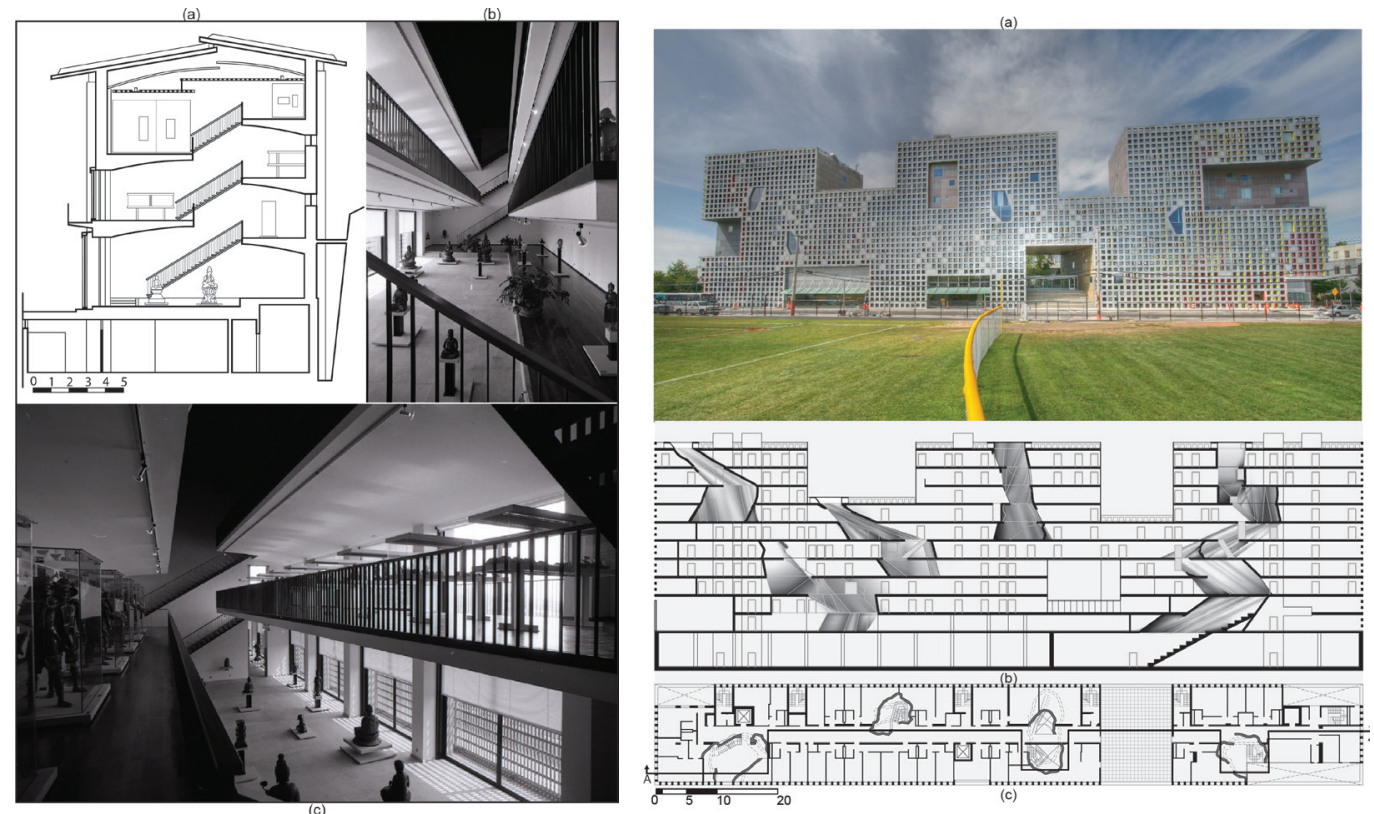
da Le Corbusier, in una versione di sviluppo verticale lungo l'altezza dell'edificio [Spesso, Porcile 20 I9, pp. 54, 55] (fig. 4). I casi sopracitati evidenziano una semplicità accentuata dalle connessioni verticali regolari che diventano punti di riferimento per la leggibilità spaziale.

La connessione tra i piani, tuttavia, può essere concepita anche attraverso elementi più complessi, come nel caso della Simmons Hall a Cambridge, Massachusetts (Steven Holl, 200 I). La residenza universitaria presenta una regolarità geometrica nella facciata che contrasta con alcune aperture irregolari che anticipano la complessità dell'interno (fig. 5a). Gli ambienti dell'edificio seguono una distribuzione piuttosto regolare, caratterizzata da un ampio percorso baricentrico su cui si affacciano i servizi e gli alloggi (fig. 5c). La linearità viene interrotta, in maniera differente a ogni piano, da ampi volumi vuoti definiti da superfici curve che sono occupati solo in minima parte dalle scale (fig. 5b).

Si tratta di elementi che si insediano all'interno dell'edificio come corpi estranei, ma capaci di connettere gli ambienti sotto diversi aspetti:

- fisico, in quanto le imponenti superfici curve diventano punti di riferimento interni ben riconoscibili per individuare le scale (fig. 6a).

- di rapporto con l'esterno, perché forniscono una connessione diretta con la copertura, quali 'polmoni' dell'edificio, portatori di aria e luce nelle zone più interne [Holl 2004, p. I53] (fig. 6b).

- sociale, nella loro funzione di luoghi di incontro tra gli abitanti dei diversi piani della residenza.

Fig. 6. Simmons Hall, Cambridge, Massachusetts; (a) Vista esterna di un volume di connessione; (b) Vista interna.

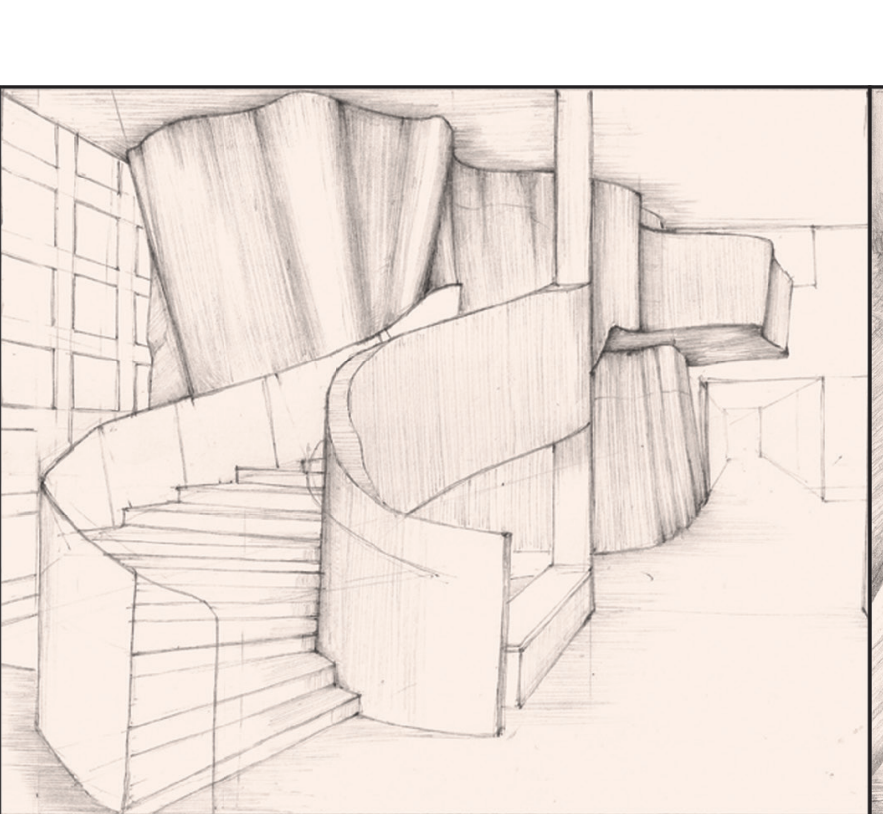

(a)

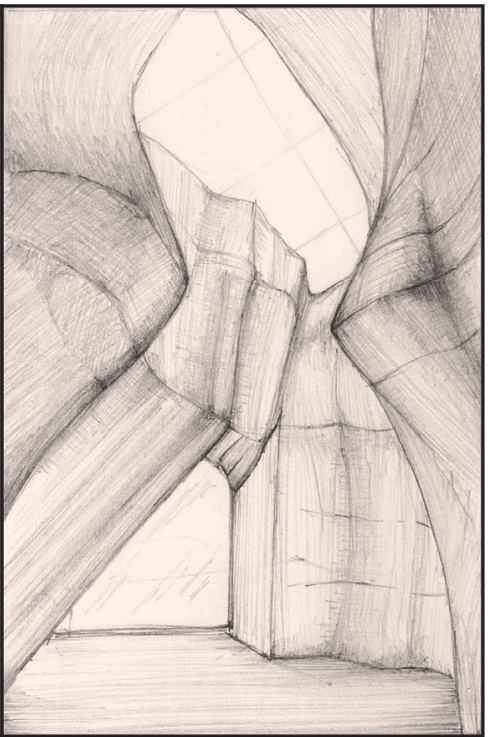

(b)

\section{I coni visuali tra cognizione e precognizione}

Oltre alle connessioni fisiche, anche quelle visive possono fornire utili elementi per il wayfinding e la ricostruzione di una mappa mentale [Weisman |98I, p. 20I]. Un elemento fondamentale per l'orientamento all'interno di un edificio complesso, infatti, è costituito dalla possibilità di percepire visivamente, almeno in parte, la sua distribuzione. La funzione è perfettamente svolta dagli affacci offerti da una posizione che permetta di osservare gli elementi distributivi o lo stesso accesso dell'edificio [Dalton Conroy et al. 20I5, p. 19]. In maniera reciproca, alcune disposizioni spaziali favoriscono 'un colpo d'occhio' fin dal primo ingresso nell'edificio, grazie all'affaccio dei piani superiori [Càndito, Castro, Meloni 2020]. La storia dell'architettura mostra una cospicua presenza di ambienti a doppia (o molteplice) altezza che, peraltro, suscitano sensazioni di dominio travalicanti la mera funzione dell'orientamento. A tale proposito si può evocare il noto dipinto della Sala dell'Olimpo a 
Fig. 7. Un affaccio su un ambiente a doppia altezza. In alto: libera trasposizion della vista sul retro del celebre dipinto con Giustiniana Giustiniani Barbaro al balcone con nutrice (Veronese, I5601562). In basso: pianta sezione.
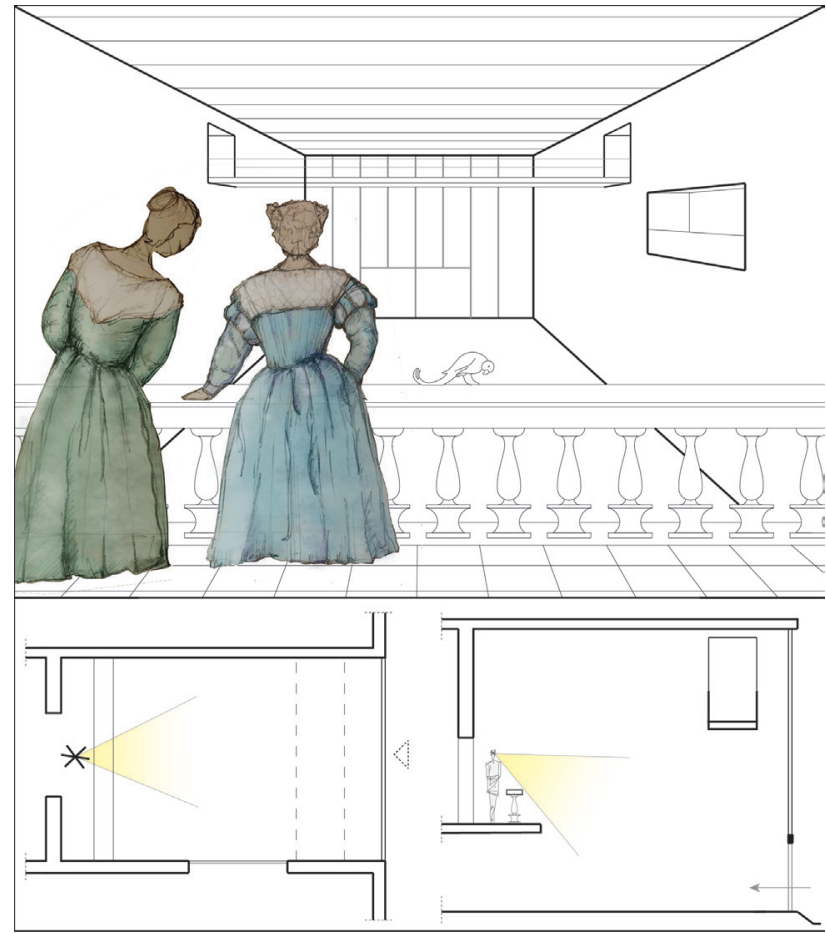

Villa Barbaro a Maser con la padrona di casa, Giustiniana Giustiniani Barbaro con nutrice al balcone (Paolo Caliari d.Veronese, I560-1562) (fig. 7). Questa modalità trova applicazione nell'orientamento nei luoghi aperti attraverso l'individuazione della propria posizione grazie alla vista offerta da un luogo elevato utile per riconoscere il contesto [Hill 1999].

Tale disposizione spaziale, dalla notevole valenza monumentale, è molto diffusa negli edifici pubblici. Un esempio significativo in tal senso si trova nella sede della British Library di Londra [St. John Wilson, Long 1998]. Gli interni sono caratterizzati dalla centrale torre di vetro fumé che contiene la collezione di Giorgio III (King's Library), ma in questa sede interessa il sistema di scale a partire dall'atrio sul quale si affacciano i diversi livelli. L'attenzione per la visione globale dello spazio è sottolineata dalla presenza di affacci circolari [5] che consentono una suggestiva vista di insieme (fig. 8).

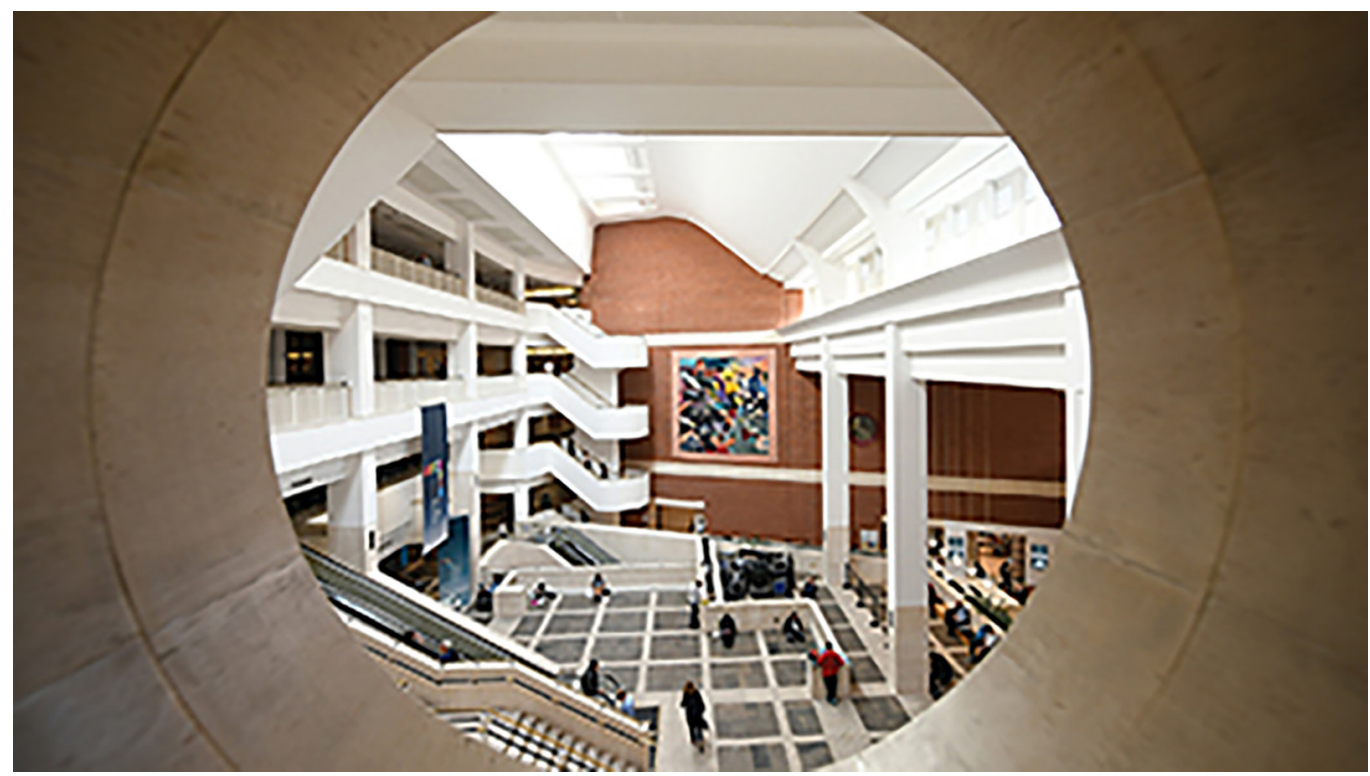


Fig. 9." "Panorama

multimediale accessibile" che traduce in versione multimediale l'immersivita di una foto sferica a $360^{\circ}$ e permette l'illustrazione di elementi nascosti alle persone vedenti e non

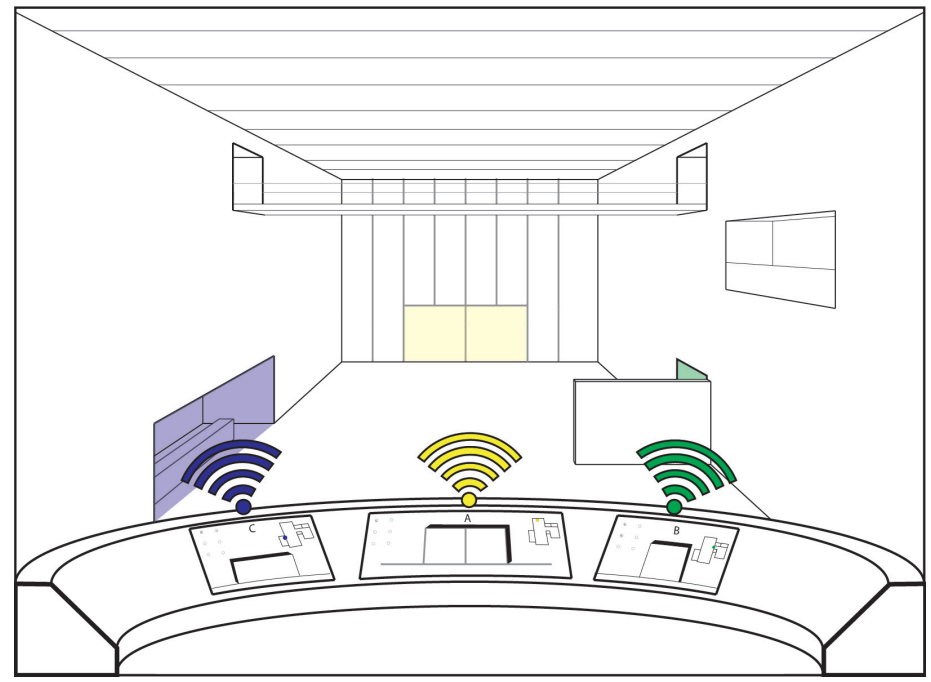

Una visuale naturale può essere corredata da apparati utili per il reperimento di informazioni sull'orientamento, ma anche per segnalare luoghi di interesse. L'accessibilità a queste informazioni può essere ampliata attraverso elementi che traducono i contenuti visivi in contenuti multisensoriali, come alcune schematiche illustrazioni e descrizioni, anche a rilievo [Empler 1997]. Ė, peraltro, ormai tecnologicamente agevole consentire agli utenti di attivare elementi testuali e sonori descrittivi o evocativi: si ottiene così un "panorama multimediale accessibile", immersivo come una foto nodale a $360^{\circ}$, ma che propone una illustrazione dei contenuti estesa anche alle persone con disabilità visive o uditive [6].

Ciò che permette una maggiore inclusione può essere utile per tutti. Un esempio è costituito dalla presenza di ostacoli visivi [Dalton Conroy et al. 20 I5, p. I8], specialmente se questi coinvolgono gli elementi distributivi e gli accessi [Hölscher et al. 2012]: I'apparato panoramico può, infatti, fornire informazioni anche quando l'intervisibilità è impedita non solo ai non vedenti (fig. 9).

Si osserva come anche la presenza di elementi molto somiglianti tra loro allinterno dello stesso edificio possa causare disorientamento [Dalton Conroy et al. 2015, p. 19]. La salienza delle caratteristiche di elementi urbani, come le facciate, è stata oggetto di studio [Nothegger et al. 2004], ma può essere interessante differenziare gli elementi chiave anche negli interni architettonici. Infatti, se una certa costanza nella distribuzione planimetrica negli edifici multipiano può essere auspicabile, nel caso delle alternative di direzione è meglio non riscontrare una perfetta uguaglianza, per non ricadere nel cosiddetto Problema di Monty Hall che suggerisce la scelta attraverso un mero calcolo statistico (fig. I0) [7].

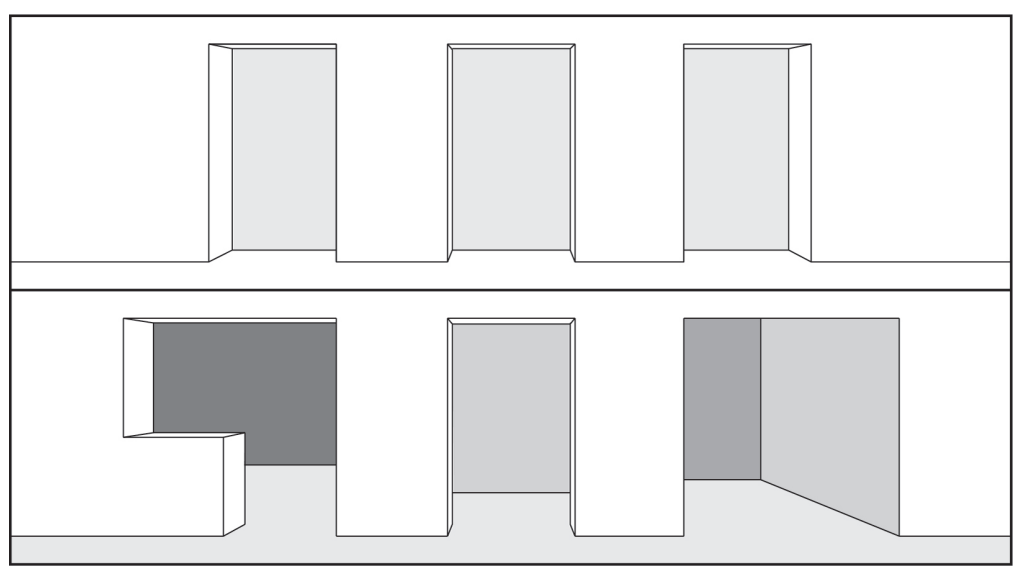


Fig. I I. I riferimenti esterni e la loro importanza per l'orientamento.

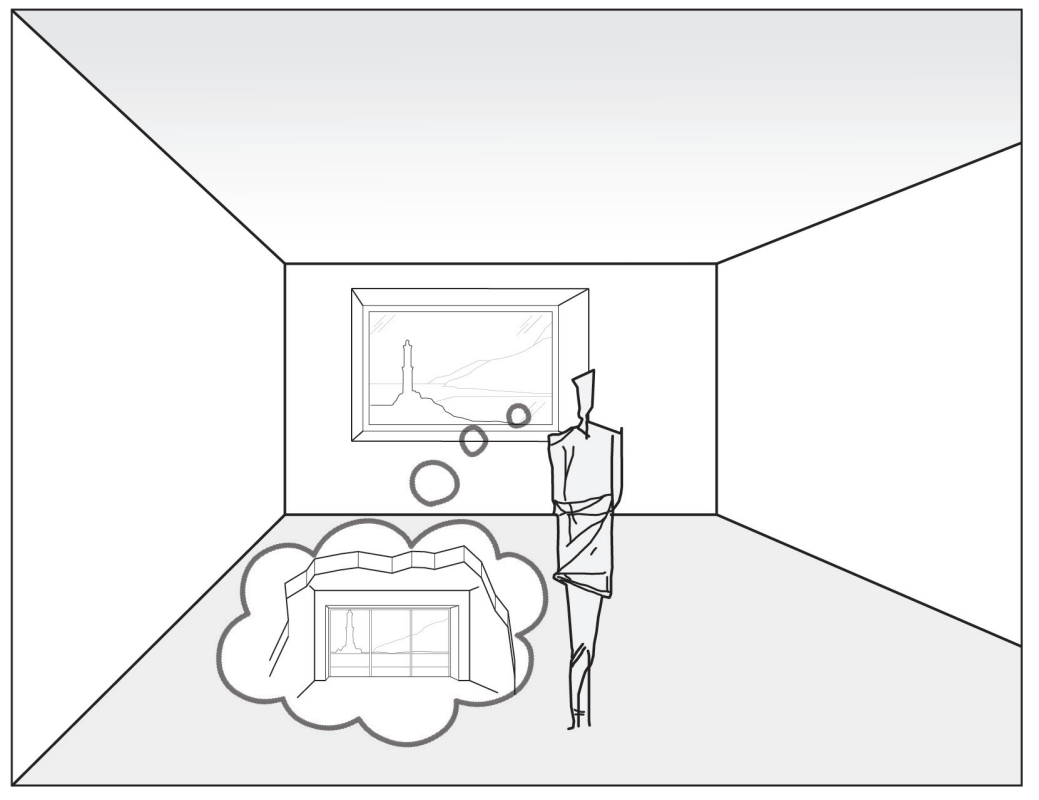

Particolare importanza nell'orientamento è ricoperta dal rapporto tra interno ed esterno, in quanto la vista di un punto di riferimento al di fuori dell'edificio permette il sicuro riconoscimento rispetto all'entrata $\mathrm{O}$ ad aperture rinvenute in altri luoghi della percorrenza [Dalton Conroy et al. 20 15, p. 19]. Si offre così anche la possibilità di gratificare le funzioni predittive che ci hanno permesso di elaborare un'ipotesi della disposizione spaziale (fig. I I) attraverso la raccolta di relazioni esperite durante la percorrenza.

Un esempio in questo senso può essere fornito dalla Casa da Musica di Porto (Studio OMA di Rem Koolhaas, 200 I) la cui complessità, talvolta disorientante, viene bilanciata grazie alla comparsa della Rotunda da Boavista con il suo il monumento (J. Marques da Silva, A. de Sousa, 1909-195I) che, alto 45 metri, celebra gli eroi della vittoria su Napoleone (1814) e riappare non solo nella sala da concerto principale, ma anche nelle terrazze e verande dei livelli superiori, come quella che è internamente rivestita da moderni azulejos (fig. I2). un'implicazione del valore dei landmark già segnalato da Kevin Lynch [1960] e che assume un valore simbolico travalicante la sola funzione legata all'orientamento.
Fig. 12. Casa da Musica, Porto.Vista del monumento della Rotunda da Boavista (foto di Jean www.ch/

29|608/44622572084/> (consultato il 20 febbraio 202I).

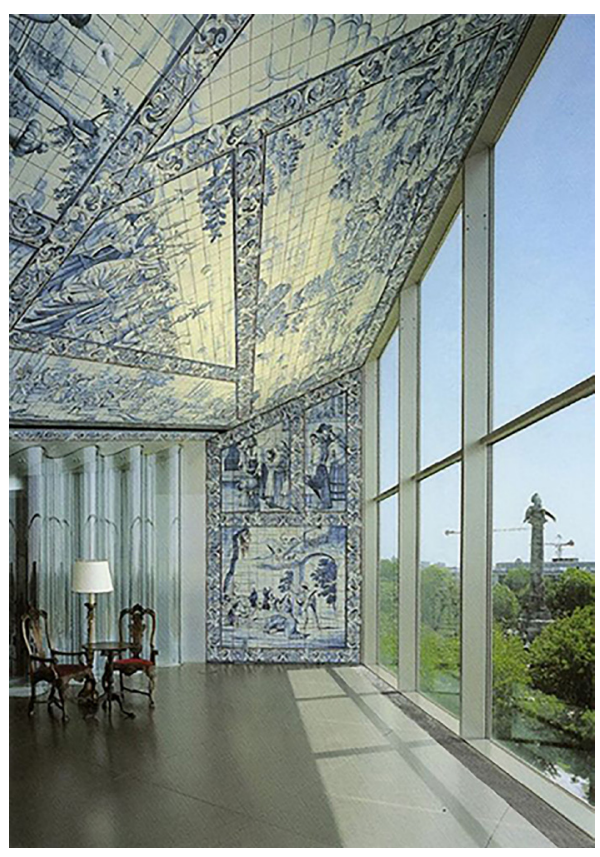




\section{Conclusioni}

Le connessioni fisiche e visuali tra lo spazio e le persone che lo praticano possono assumere svariati significati e fornire indizi utili per la risoluzione del problema di base dell'orientamento, che consiste nel raggiungimento della destinazione. Appare, però, interessante anche la possibilità di ricorrere alla reciprocità per addestrare alla capacità di riconoscere e ricostruire il percorso effettuato, fino a permettere di trarre indicazioni globali sul luogo praticato e arrivare a redigerne una mappa mentale. Al raggiungimento di questo scopo sembrano contribuire principalmente le percezioni visive che sono però coadiuvate dalle altre sensazioni, specialmente tattili e sonore, che integrano le informazioni visuali o le sostituiscono nel caso di disabilità sensoriali. Per questo motivo si sono integrate le illustrazioni schematiche di casi ideali con quelle delle architetture reali, non considerate quali casi studio ma come esempi di significative caratteristiche spaziali legate all'orientamento.

\section{Crediti}

II presente studio è stato condotto con i fondi del progetto di Rappresentazione architettonica inclusiva (Progetti di Ricerca di Ateneo 2019. Università di Genova), che coinvolge entrambi gli autori.

Lo studio è frutto della collaborazione tra i due autori, ma il paragrafo "Connessioni spaziali fisiche tra orientamento e percezione" è stato redatto da Alessandro Meloni, mentre il resto da Cristina Càndito. Le figure, ove non altrimenti indicato, sono state ideate in collaborazione e realizzate da Alessandro Meloni.

\section{Note}

[1] Aristotele, Anima, a cura di Giancarlo Movia, Milano, 1996, p. 205.

[2] Questo fattore nell'ambito di Space Syntax viene denominato Angularity e Angularity Choice: il fruitore di uno spazio valuta più esteso un percorso con molti cambi di direzione [Dalton Conroy 2003].

[3] II progetto prevede la ricostruzione e restauro del convento di Sant'Agostino fortemente danneggiato dai bombardamenti bellici. L'utilizzo prevalente dell'acciaio, con travi a luce libera di oltre 30 metri, consente di connettere le nuove costruzioni con l'esistente per definire spazi ampi e fluidi [Helg 1979].

[4] Alla morte di Mario Labò (1961) subentrò Giorgio Olcese (1963) e, nel 1967, Luciano Grossi Bianchi, Cesare Fera e Caterina Marcenaro si occuparono dell'allestimento museale.

[5] II descritto oblò e altre caratteristiche formali degli interni rimandano alle immagini di una nave e le loro origini vengono attribuite alla precedente carriera di Colin, come ufficiale della marina.

[6] I "panorami multimediali accessibili" sono allo studio da parte di chi scrive nell'ambito del progetto di ricerca citato.

[7] II "Paradosso di Monty Hall" deriva dal soprannome del conduttore del gioco televisivo che poneva la scelta tra tre porte, di cui una celava il premio dell'automobile e le altre una capra ciascuna. Se la prima scelta (con I/3 delle probabilità) risultava sbagliata, il presentatore scopriva la rimanente errata e offriva lo scambio che se accettato, al contrario di quello che l'intuizione suggerisce, aumentava le probabilità di vincita.

\section{Riferimenti bibliografici}

Berdik C. (2009). Lost; Birds, rats and even hamsters are able to find their way [...] Why humans can't navigate out of a paper bag. In New Scientist, n. 2721, pp. 30-33.

Bucci M., Rossari A. (a cura di). (2005). I musei e gli allestimenti di Franco Albini. Documenti di architettura. Milano: Electa.

Càndito C., Castro A., Meloni A., (2020). Rappresentazione, percezione e wayfinding. L'architettura per l'università del passato e del presente. In A. Arena et al. (a cura di). Connettere. Un disegno per annodare e tessere. Atti del $42^{\circ}$ Convegno internazionale dei Docenti della Rappresentazione. XVII Congresso U.I.D., pp. I 820- I 84 I. Milano: Franco Angeli.

Dalton Conroy R. (2003). The Secret Is To Follow Your Nose: Route Path Selection and Angularity. In Environment and Behavior, 35, n. I, pp. |07-|3|.

Dalton Conroy. R., Hölscher C., Spiers H. J. (20I5). Navigating Complex Buildings: Cognition, Neuroscience and Architectural Design. In Studying Visual and Spatial Reasoning for Design Creativity, pp. 3-22. Netherlands: Springer.

Empler T. (1997). Progettare il comfort urbano e d'interni: Guida ad una progettazione plurisensoriale. Rimini: Maggioli.

Gibson J. J. (1979). The ecological approach to visual perception. Boston: Houghton Mifflin Company.

Golledge R. G., Stimson R. J. (1997). Spatial behavior: a geographic perspective. New York: Guilford Press.

Helg F. (1979). II museo di Sant'Agostino nel centro storico di Genova. In Casabella, n. 443, pp. 28-33. 
Hill K. (1998). The Psychology of Lost. In K. Hill (a cura di). Lost Person Behavior, pp. I - I 5. Ottawa, Canada: National SAR Secretariat.

Hillier B. (2007). Space Is the Machine: A Configurational Theory of Architecture. London: Space Syntax.

Holl S. (2004). Parallax. Architettura e percezione. Milano: Postmedia Srl.

Hölscher C., Brösamle M.,Vrachliotis G. (20I2). Challenges in multilevel wayfinding: a case study with the space syntax technique. In Environment and planning B: Planning and Design, 39, n. I, pp. 63-82.

Lynch K. (1960). The image of the city. Cambridge, Mass: MIT Press.

Mallgrave H. F. (2013). Architecture and Embodiment. The implication of the new sciences and Humaties for Design. London: Routlgedge.

Nothegger C., Winter S., Raubal M. (2004). Selection of Salient Features for Route Directions. In Spatial Cognition and Computation, n. 4, pp. | |3-136.

Papadopoulos K., Koustriava E., Barouti M. (2017). Cognitive Maps of Individuals with Blindness for Familiar and Unfamiliar Spaces: Construction through Audio-Tactile Maps and Walked Experience. In Computers in Human Behavior, n. 75, pp. 376-384.

Robinson S., Pallasmaa J. (20I5). Mind in architecture: Neuroscience, embodiment, and the future of design. Cambridge Mass.: MIT Press.

Spesso M., Porcile G. L. (2019). Da Zevi a Labò, Albini e Marcenaro: Musei a Genova 1948-1962: intersezioni tra razionalismo e organicismo. Genova: University Press.

Weisman J. (1981). Evaluating Architectural Legibility: Way-Finding in the Built Environment. In Environment and Behavior, I3, n. 2, pp. $\mid 89-204$.

\section{Autori}

Cristina Càndito, Università di Genova, cristina.candito@unige.it

Alessandro Meloni, Università di Genova, arch.melonialessandro@gmail.com

Per citare questo capitolo: Càndito Cristina, Meloni Alessandro (2021). Il contributo della rappresentazione alla percezione dell'architettura. Orientamento, connessioni spaziali e accessibilità/The contribution of representation to the perception of architecture. Orientation, spatial connec tions and accessibility. In Arena A., Arena M., Mediati D., Raffa P. (a cura di). Connettere. Un disegno per annodare e tessere. Linguaggi Distanze Tecnologie. Atti del $42^{\circ}$ Convegno Internazionale dei Docenti delle Discipline della Rappresentazione/Connecting. Drawing for weaving relationship. Languages
Distances Technologies. Proceedings of the $42^{\text {th }}$ International Conference of Representation Disciplines Teachers. Milano: FrancoAngeli, pp. $1415-1434$. 


\title{
The Contribution of Representation to the Perception of Architecture. Orientation, Spatial Connections and Accessibility
}

\author{
Cristina Càndito \\ Alessandro Meloni
}

Abstract

The field of investigation of this paper includes elements related to spatial orientation and their transposition through perception, involving the concept of mental representation, with implications that go beyond the scope of wayfinding. The subjects studied are architectural interiors, both in their ideal characteristics, that help or complicate the function of orientation, and through real architecture, capable of properly illustrating some of these peculiarities. We have used studies and research carried out in the field of architecture and neurocognitive sciences and we have applied methodologies typical of the field of representation, which allow us to simulate spatial situations or highlight some aspects of existing architecture. We have observed how the characteristics described can be classified according to two types of connection -or distance reduction- between space and user: physical and visual. During the study we have found that the mental image, which involves various neurocognitive aspects, can also be favoured by factors based not only on sight. These elements are also useful for making spatial perception inclusive for people with sensory disabilities, with attention to accessibility that involving not only functional aspects of architecture.

Keywords

perceptions, orientation, wayfinding, accessibility, multisensoriality.

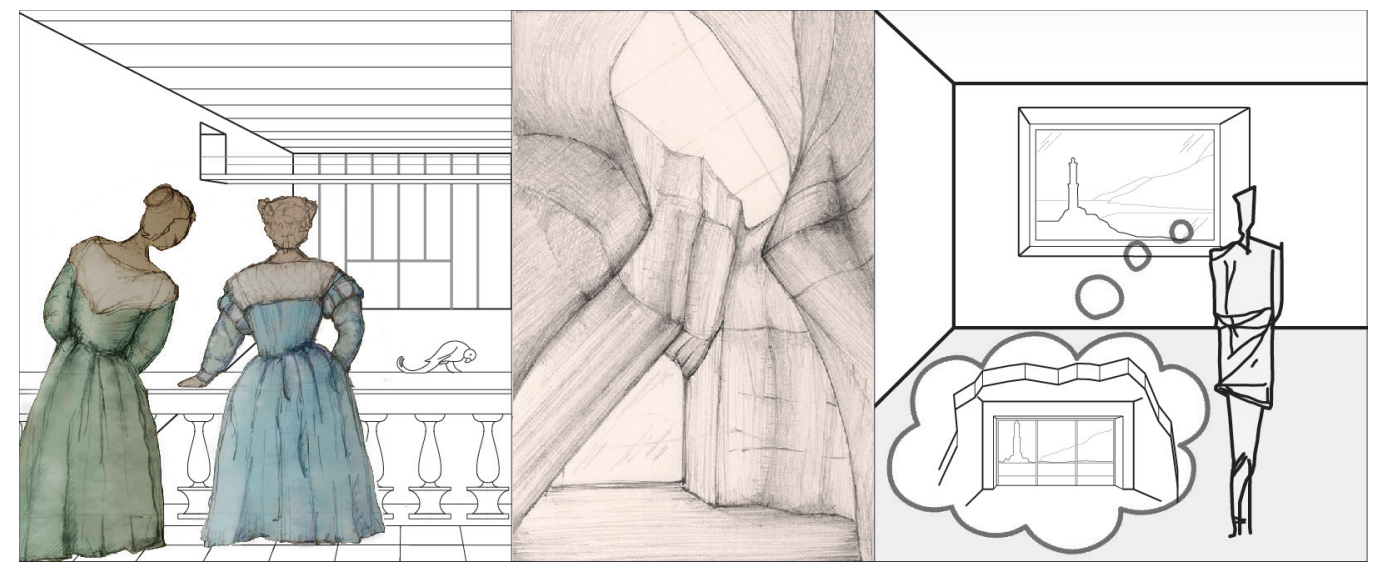


"(L'immaginazione) dipende da noi [...] è possibile, infatti, raffigurarsi qualcosa davanti agli occhi, come fanno coloro che dispongono le cose nei luoghi mnemonici e si costruiscono immagini". [Aristotele, De anima, III, 3, 427b] [I].

\section{Orientation in space and representation}

The knowledge of a spatial configuration is based on its mental representation: the traces collected through the senses and their perception allow the generation of maps useful for orientation inside the buildings, as well as arousing articulated and engaging interpretations. This contribution investigates some characteristics of the perceptual impact generated within architecture, focusing on elements related to orientation analysed through the methods of the disciplines of representation. The 'sense of direction' finds a synthesis in the formulation of a 'cognitive map' in the hippocampus area, after having involved different parts of the brain [Berdik 2009] since it is a skill that affects the environment, with its perception and his memory, but also the body, with its position and movements. For this reason, we have considered research on wayfinding [Lynch 1960; Golledge, Stimson 1997], also in the Space Syntax field (set of theories, methods and tools aimed at describing the phenomena of relationship between space and society) [Hillier 1996, ed. 2007] and some studies specifically concerning orientation within complex buildings, integrating neurocognitive and architectural fields [Dalton Conroy et al. 20I5].

The methods of investigation typical of representation have suggested to us the usefulness of translating into images some characteristics described by previous research, to discover new implications and identify their functional classification according to two types of connection -or reduction of distances- between space and user: the physical ones and those that are based on visual elements. These characteristics were also analysed through real architectures, which are not considered as case studies but as examples to set up a critical dialogue with other architectural properties and to extend the considerations to non-visual perceptions [Mallgrave 20 I3; Robinson, Pallasmaa 20I5]. In this field, the dialogue with experiences that deepen the knowledge of space in the presence of visual impairments is fruitful [Papadopoulos 20 17]. The present study, in fact, is part of a broader research on accessibility, understood not only as a functional use of architecture, but as a promotion of inclusion and the simultaneous implementation of the expressiveness of spatial characteristics.

Fig. I.The changes of direction. (a) Turning less than 90 degrees is mentally traced back to a perpendicular Change of direction. (b) Disorientation caused by a turn greater than degrees
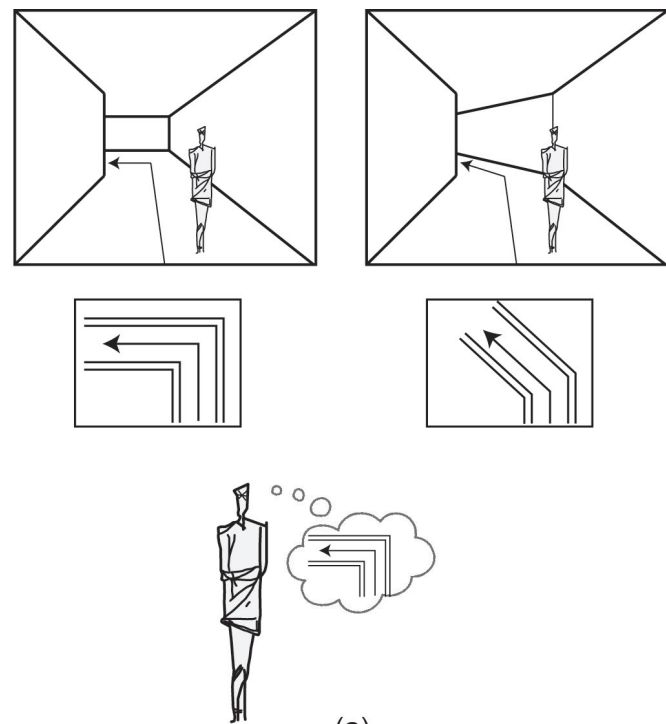

(a)
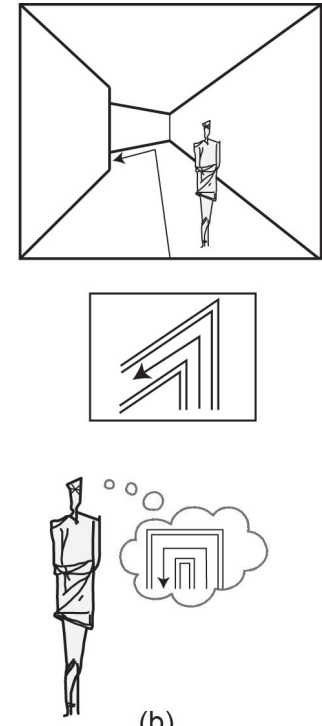

(b) 


\section{Physical spatial connections between orientation and perception}

During the process of space exploration, its mental reconstruction plays an important role as it allows the main elements useful for orientation to be extrapolated. The changes of direction that occur inside a building, for example, can influence the behaviour and perception of the space covered. Generally, the user is more inclined to undertake straight paths [2] and with curves with turning angles less than or equal to 90 degrees (fig. Ia); a greater turning point, in fact, would seem to lead back to the origin, thus generating disorientation (fig. Ib) [Dalton Conroy et al. 20 I5, pp. I8, 19]. This process of schematizing the path favours memory and facilitates the possibility of retracing the space: an innate need that can be traced back to the survival instinct [Dalton Conroy 2003]. It is possible to highlight the attitudes that occur above all in multi-storey buildings which, due to spatial and distributive characteristics, are more complex; users exploring these environments assume that the main elements of each floor are equally arranged [Dalton Conroy et al. 20 I 5, p. 19].

(a)

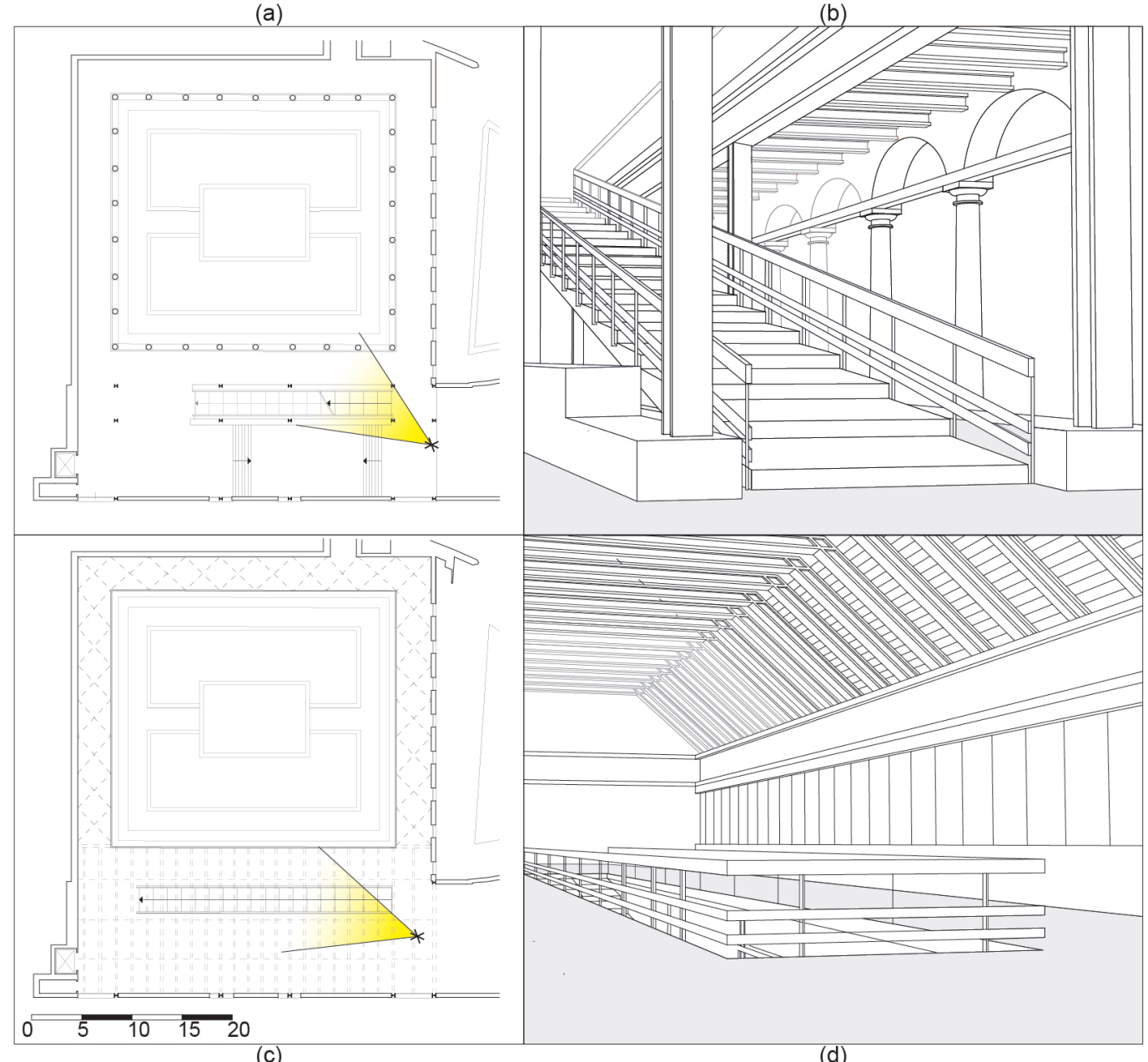

Fig. 2. Sant'Agostino Museum, Genoa. (a) First floor plan. (b) View of the first floor wher the arches delimiting the eighteenth-century cloister are highlighted. (c) Second floor plan. (d) View of the second floor highlighting the continuous series of windows. (c)

(d)

Among the many examples that can be identified, the Sant'Agostino Museum in Genoa (Franco Albini, 1963-1979) [3] emphasizes this aspect through the central flight of stairs, which is repeated on each floor, becoming the reference point for navigation within the building (fig. 2a, c). The model is the Genovese staircase, in which the depth of the tread in relation to a reduced rise allows to assimilate it to a sloping ramp, which leads to a slow 
Fig. 3. Sant'Agostino Museum, Genoa; (a) First floor plan: in red the steel structure of the floor; (b) Section $A-A$ ', where the chain of the roof trusses are highlighted; (c) Internal view: in red, the beams of the structure.
Fig. 4. Davide Chiossone Museum, Genoa. (a) Section highlighting the layout of the floors. (b) (c) Interior space (c) (97।) hy Paolo Monti, . (202). 2021, February 20).

Fig. 5. Simmons Hall, Cambridge, Massachusetts. (a) External view <https:// commons.Wikımedia. org/> (accessed 2021 February 20); (b) Section A-A'; (c) Seventh floor plan.

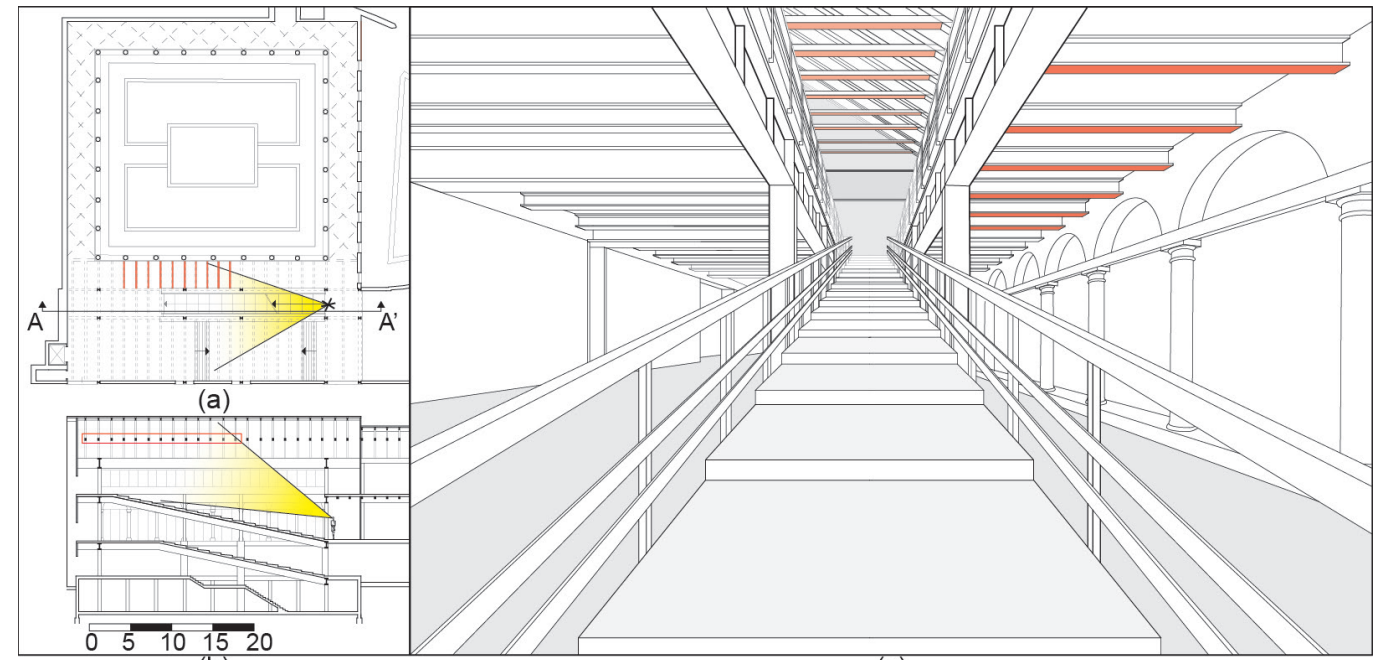

(b)

ascent to the upper floor, ideal for grasping the spatial quality more fully. In addition, the architectural elements that define the view over the eighteenth-century cloister vary at each level, facilitating the recognition of the different floors (fig. $2 b, d$ ). The repetition of the exposed steel beams becomes an element that is also found on the top floor, with the chains of the trusses (fig. 3): a repetition that can be considered 'plethoric' [Bucci, Rossari 2005, p. $58]$ but which highlights the spatial scan useful for internal orientation.

A similar perception can also be found inside the Davide Chiossone Museum of Oriental Art in Genoa (Mario Labò, 1948-197I) [4]. It is an architecture defined by simple elements that hide complexities related to geometry and the distribution system. The exhibition space is divided into five staggered levels that are arranged close to the main sides of the building and internally overlook a full-height space that visually connects the entire volume. The characterizing aspect is determined by the distribution: the steel and wood stairs are arranged at the ends of the levels except for the last one, where the staircase is 90 degrees rotated to allow the definition of a cyclical and intuitive path. It is a reinterpretation of the concept of the "continuous and unlimited growth museum" developed by Le Corbusier, in
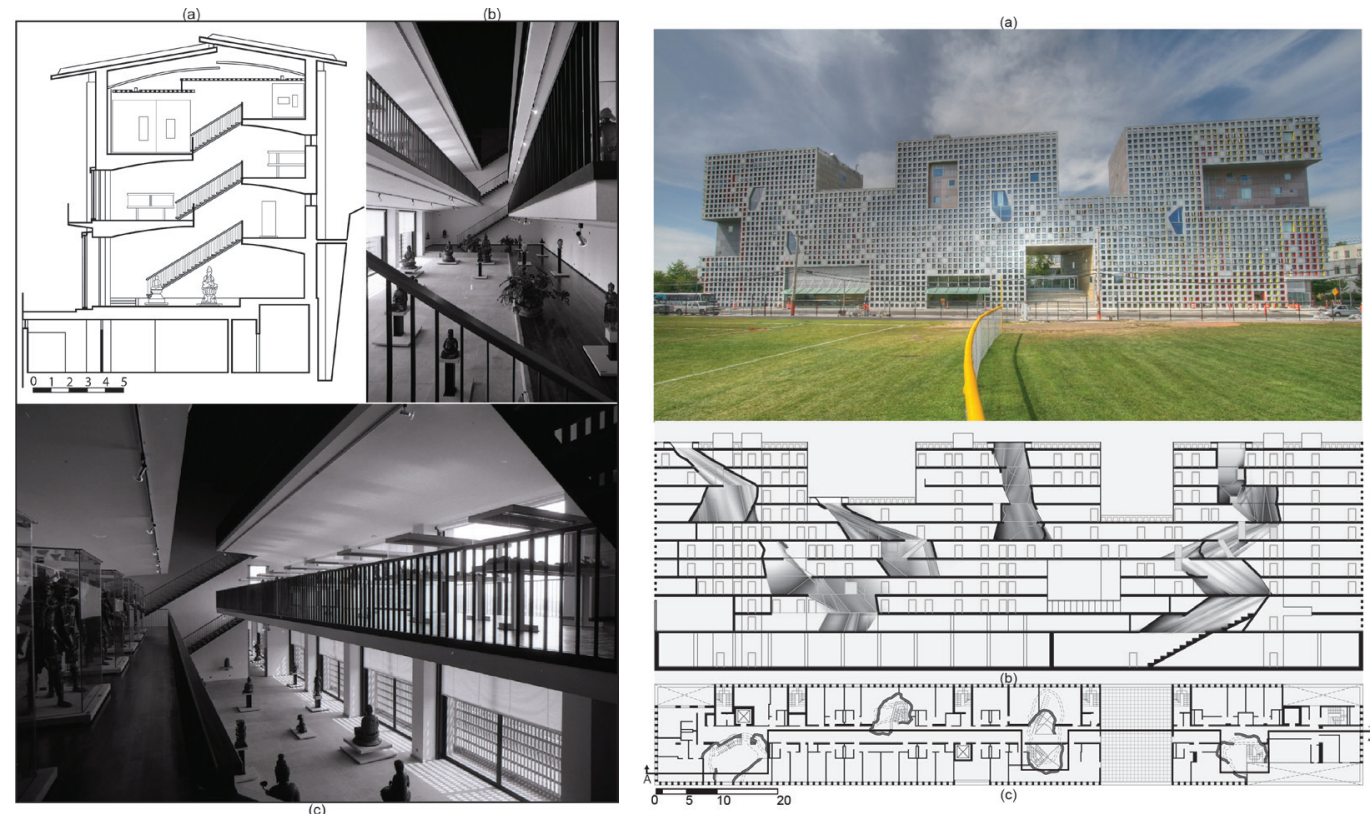
a version of vertical development along the height of the building [Spesso, Porcile 2019, pp. 54, 55] (fig. 4). The aforementioned cases highlight a simplicity accentuated by regular vertical connections that become reference points for spatial legibility.

The connection between the floors, however, can also be conceived through more complex elements, as in the case of Simmons Hall in Cambridge, Massachusetts (Steven Holl 200 I). The university residence has a geometric regularity in the facade that contrasts with some irregular openings that anticipate the complexity of the interior (fig. 5a). The rooms of the building follow a fairly regular distribution, characterized by a wide barycentric path overlooked by the services and accommodation (fig. 5c). The linearity is interrupted, in a different way on each floor, by large empty volumes defined by curved surfaces which are only minimally occupied by the stairs (fig. $5 b$ ).

These are elements that settle inside the building as foreign bodies, but capable of connecting the environments in different respects:

- physical, as the imposing curved surfaces become internal easily recognizable reference points for identifying the stairs (fig. 6a).

- of relationship with the outside, because they provide a direct connection with the roof, such as "lungs" of the building, carriers of air and light in the innermost areas [Holl 2004, p. I53] (fig. 6b).

- social, in their function of meeting places between the inhabitants of the different floors of the residence.

Fig. 6. Simmons Hall, Cambridge, Massachusetts; (a) External view of a connection volume; (b) Internal view.

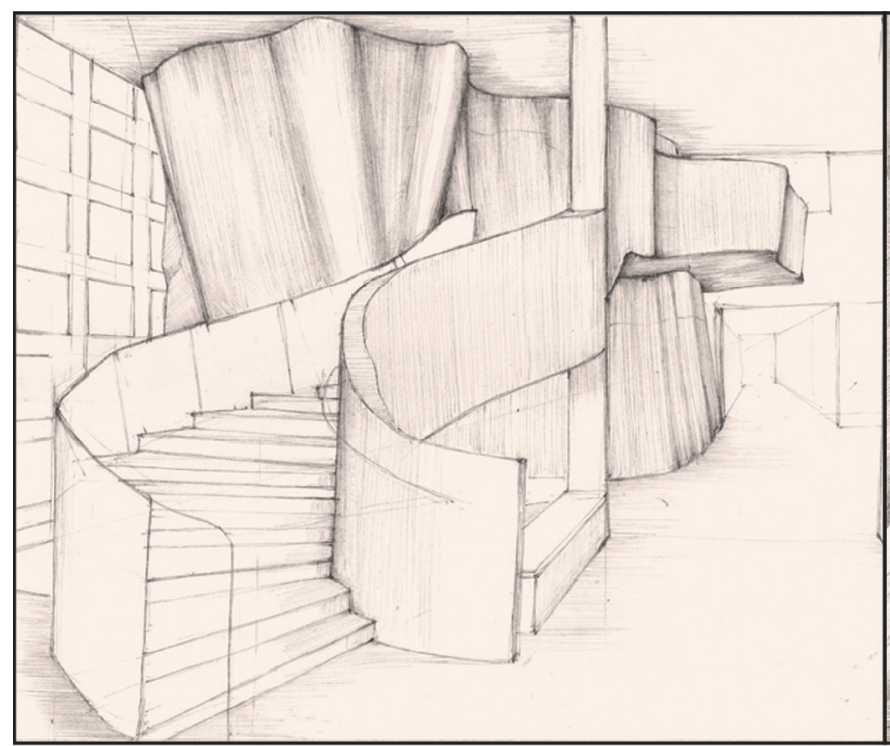

(a)

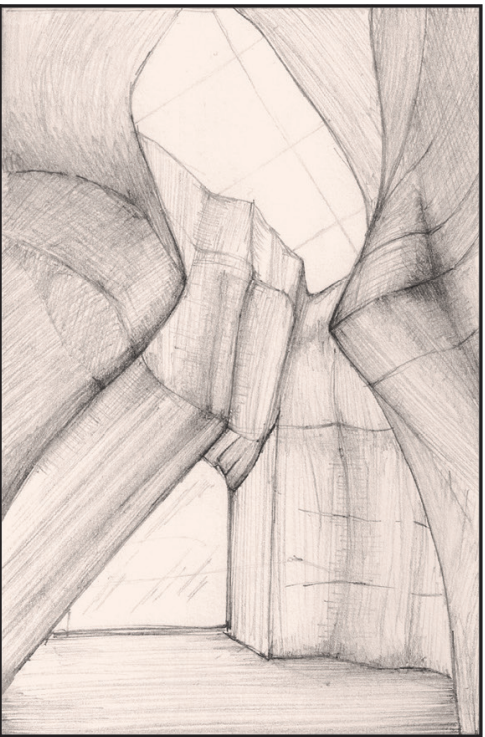

(b)

Visual cones between cognition and precognition

In addition to physical connections, visual ones can also provide useful elements for wayfinding and the reconstruction of a mental map [Weisman 198I, p. 20 I].A fundamental element for orientation within a complex building, in fact, is the ability to visually perceive, at least in part, its distribution. The function is perfectly performed by the views offered by a position that allows you to observe the distributive elements or the access of the building itself [Dalton Conroy et al. 20 I5, p. 19]. In a reciprocal way, some spatial arrangements favour a glance from the first entrance into the building, thanks to the view of the upper floors [Càndito, Castro, Meloni 2020].

The history of architecture shows a conspicuous presence of double (or multiple) height environments which, moreover, arouse feelings of domination that go beyond the mere function of orientation. In this regard, we can recall the well-known painting in the Hall of 
Fig. 7. A double height space view. Above: free transposition of the rear view of the famous painting with Giustinian Giustiniani Barbaro on the balcony with nurse (Veronese, |560-1562). Below: plan and section.
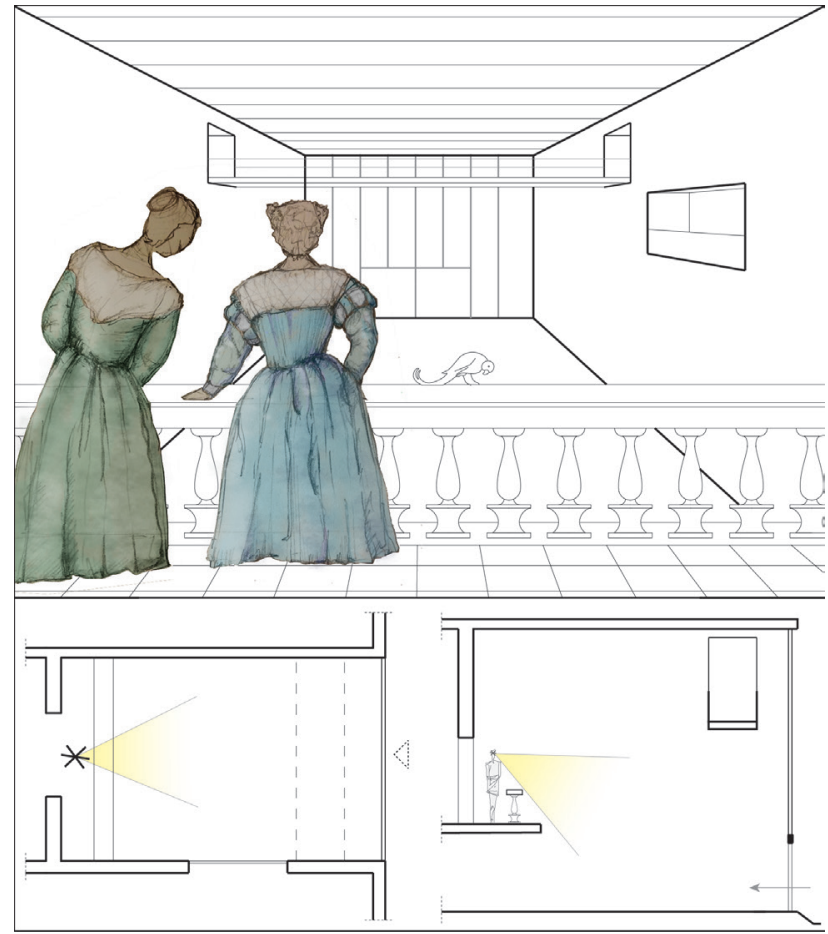

Olympus at Villa Barbaro in Maser with the lady of the house, Giustiniana Giustiniani Barbaro with a nurse on the balcony (Paolo Caliari d.Veronese, I 560- I562) (fig. 7). This mode is applied in orientation in open places by identifying one's position thanks to the view offered by an elevated place useful for recognizing the context [Hill 1999].

This spatial arrangement, of considerable monumental value, is very common in public buildings. A significant example of this is found in the building of the British Library in London (Colin St. John Wilson and MJ Long, 1998). The interiors are characterized by the central smoked glass tower that contains the collection of George III (King's Library), but here the system of stairs starting from the atrium overlooked by the different levels is of interest. The attention to the global vision of the space is underlined by the presence of circular openings [5] that allow a suggestive overall view (fig. 8).

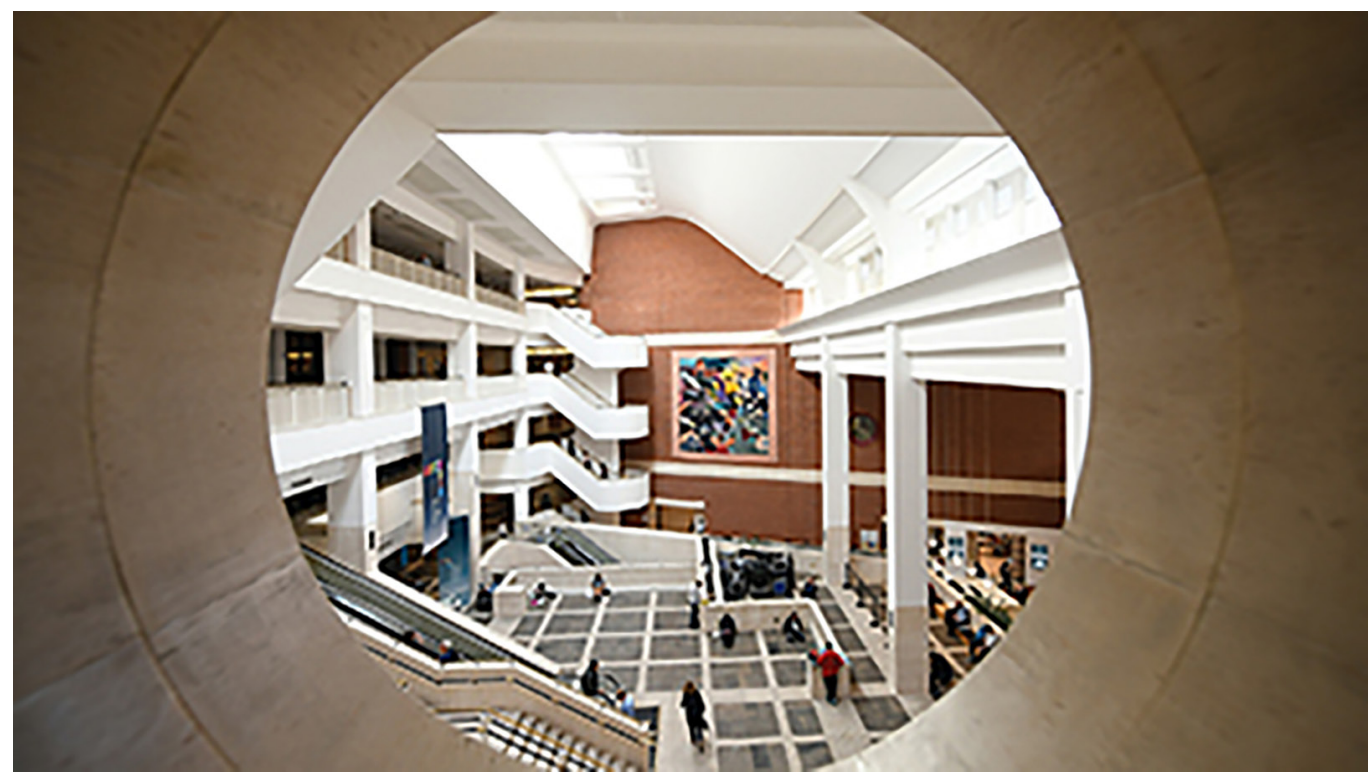


Fig. 9."Accessible multimedia panorama" that translates the immersion of a 360 degrees spherical photo into a multimedia version and allows the illustration of hidden elements for sighted and non-sighted people.

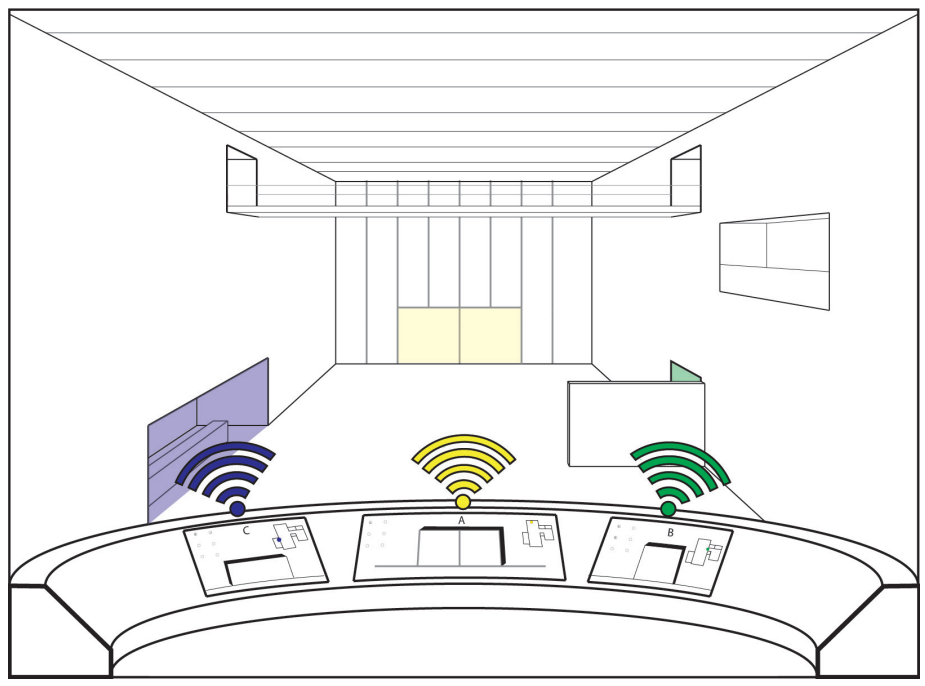

A natural view can be accompanied by devices useful for finding information on orientation, but also for indicating places of interest. Accessibility to this information can be expanded through elements that translate the visual content into multisensory content, such as some schematic illustrations and descriptions, also in relief [Empler 1997]. Moreover, it is currently technologically easy to allow users to activate descriptive or evocative textual and sound elements: in this way an "accessible multimedia panorama" is obtained, as immersive as a nodal 360 degrees photo, but which also offers an illustration of the contents extended to people with visual or hearing impairments [6].

What allows for greater inclusion can be beneficial for everyone. An example is the presence of visual obstacles [Dalton Conroy et al. 20 I5, p. I8], especially if these involve distributive elements and accesses [Hölscher et al. 2012]: the panoramic apparatus can, in fact, provide information even when intervisibility is prevented not only for the blind (fig. 9).

It is observed that even the presence of very similar elements within the same building can cause disorientation [Dalton Conroy et al. 2015, p. 19]. The salience of the characteristics of urban elements, such as facades, has been the subject of studies [Nothegger et al. 2004], but it can be interesting to differentiate the key elements also in the architectural interiors. In fact, if a certain constancy in the planimetric distribution in multi-storey buildings may be desirable, in the case of alternatives of direction it is better not to find perfect equality, not to fall back into the so-called Monty Hall Problem which suggests the choice through a mere statistical calculation (fig. I0) [7].
Fig. 10.The choice of direction. Above: the Monty Hall Paradox which suggests the choice between three doors through a statistical calculation. Bottom: a formal differentiation of alternatives.

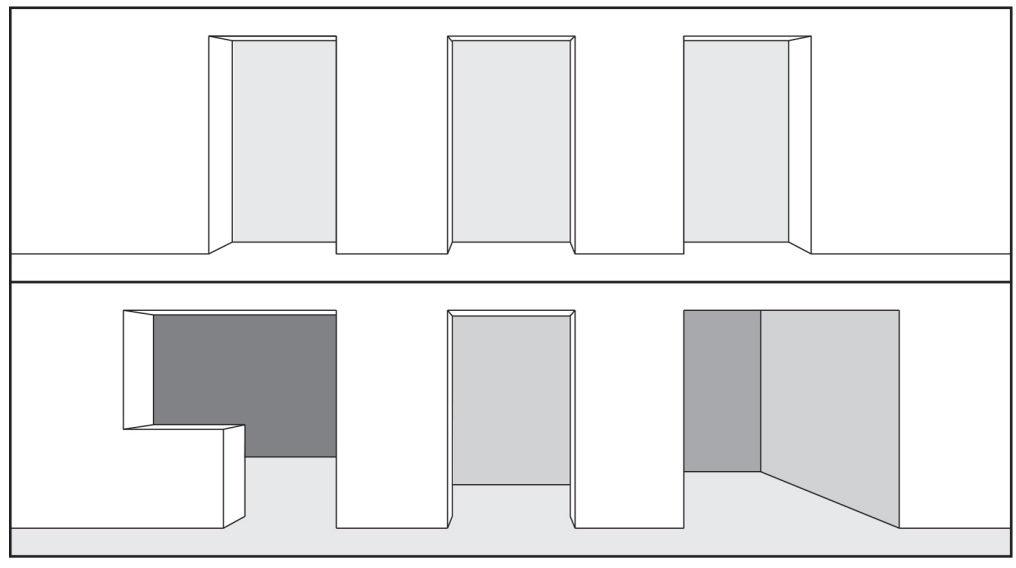




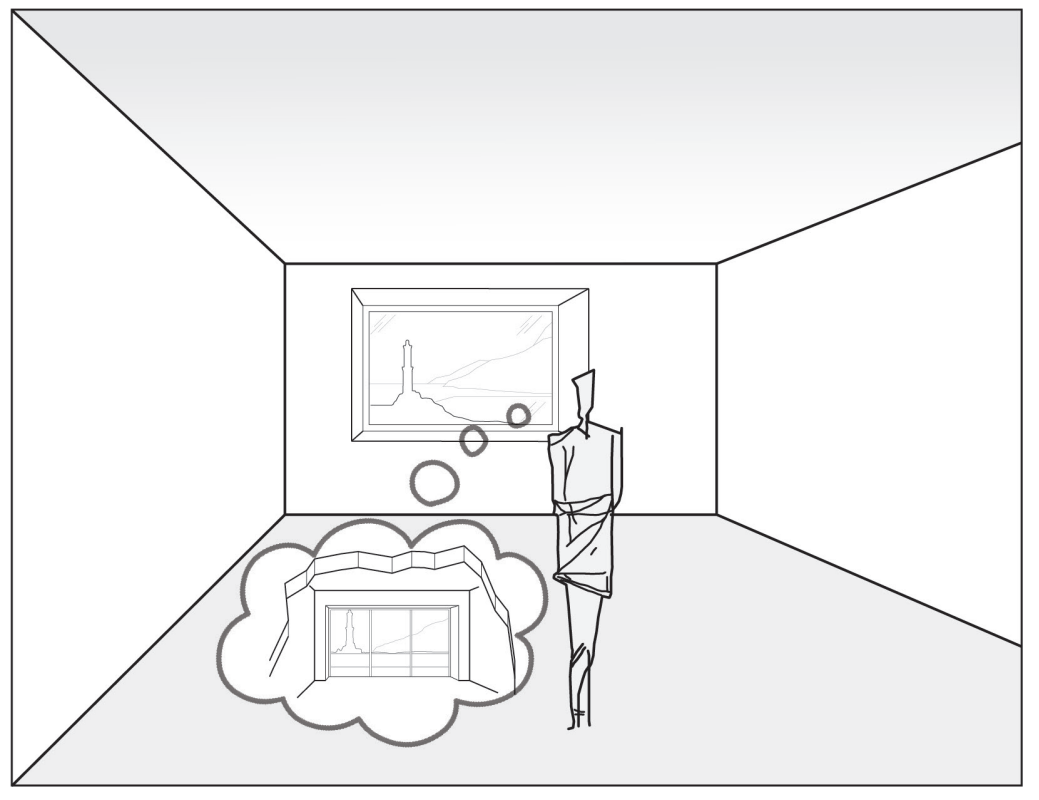

Particular importance in orientation is covered by the relationship between inside and outside, as the sight of a reference point outside the building allows for sure recognition with respect to the entrance or to openings found in other places along the way [Dalton Conroy et al. 20 I5, p. 19]. This aspect also offers the possibility of gratifying the predictive functions that have allowed us to develop a hypothesis of the spatial arrangement (fig. II) through the collection of relationships experienced during the journey.

An example in this sense can be provided by the Casa da Musica in Porto (Studio OMA by Rem Koolhaas, $200 \mathrm{I}$ ) whose complexity, sometimes confusing, is balanced by the appearance of the Rotunda da Boavista with its monument (J. Marques da Silva , A. de Sousa, 1909195I) which, 45 meters high, celebrates the heroes of the victory over Napoleon (1814) and reappears not only in the main concert hall, but also in the terraces and verandas of the upper levels, such as the one that is internally covered with modern azulejos (fig. 12). It is an implication of the value of landmarks already reported by Kevin Lynch [1960] and which takes on a symbolic value that goes beyond the sole function linked to orientation.

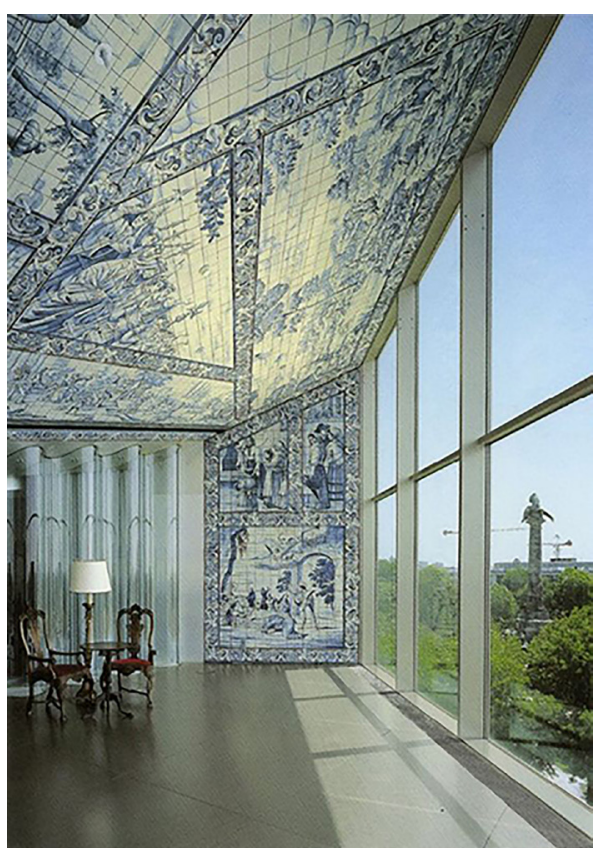

Fig. 12. Casa da Musica, Porto. View of the Rotunda da Boavista (photo by Jon Paul (photo by Jean Pau warrarte):

29|608|44622572084/> (accessede 2021 February 20). 


\section{Conclusions}

The physical and visual connections between the space and the people who practice it can take on various meanings and provide useful clues for solving the basic problem of orientation, which consists in reaching the destination. However, the possibility of resorting to reciprocity to train in the ability to recognize and reconstruct the path taken is also interesting, to the point of allowing global indications on the place practiced and to draw up a mental map. To achieve this goal, visual perceptions seem to contribute mainly but are assisted by other sensations, especially tactile and sound, which integrate visual information or replace it in the case of sensory disabilities. For this reason, the schematic illustrations of ideal cases have been integrated with those of real architectures, not considered as case studies but as examples of significant spatial characteristics related to orientation.

\section{Credits}

This study has been conducted with funding from the Inclusive architectural representation project (University Research Projects 2019, University of Genoa), which involves both authors. The study is the result of the collaboration between the two authors, but the paragraph "Physical spatial connections between orientation and perception" was written by Alessandro Meloni, while the rest by Cristina Càndito. The figures, unless otherwise indicated, were designed in collaboration, and created by Alessandro Meloni.

\section{Notes}

[I] Aristotele, Anima. Giancarlo Movia (Ed.), Milano, 1996, p. 205.

[2] This factor is called Angularity and Angularity Choice by Space Syntax: the user of a space considers more extended a path with many changes of direction. [Dalton Conroy 2003]

[3] The project involves the reconstruction and restoration of the convent of Sant'Agostino heavily damaged by war bombings. The prevalent use of steel, with free-span beams of over 30 meters, makes it possible to connect the new buildings with the existing ones to define large and fluid spaces [Helg 1979].

[4] On the death of Mario Labò (1961), Giorgio Olcese (1963) took over and, in 1967, Luciano Grossi Bianchi, Cesare Fera and Caterina Marcenaro took care of the museum set-up.

[5] The described porthole and other formal interior features refer to images of a ship and their origins are attributed to Colin's previous career as a naval officer.

[6] The "accessible multimedia panoramas" are being studied by the writer as part of the aforementioned research project.

[7] The "Monty Hall Paradox" derives from the nickname of the host of the television game who placed the choice between three doors, one of which concealed the car prize and the other a goat each. If the first choice (with I/3 of the probability) was wrong, the presenter discovered the remaining one wrong and offered the exchange that if accepted, contrary to what intuition suggests, increased the chances of winning.

\section{References}

Berdik C. (2009). Lost; Birds, rats and even hamsters are able to find their way [...] Why humans can't navigate out of a paper bag. In New Scientist, n. 272 I, pp. 30-33

Bucci M., Rossari A. (a cura di). (2005). I musei e gli allestimenti di Franco Albini. Documenti di architettura. Milano: Electa.

Càndito C., Castro A., Meloni A., (2020). Rappresentazione, percezione e wayfinding. L'architettura per l'università del passato e del presente. In A. Arena et al. (a cura di). Connettere. Un disegno per annodare e tessere. Atti del $42^{\circ}$ Convegno internazionale dei Docenti della Rappresentazione. XVII Congresso U.I.D., pp. I820- I84I. Milano: Franco Angeli.

Dalton Conroy R. (2003). The Secret Is To Follow Your Nose: Route Path Selection and Angularity. In Environment and Behavior, 35, n. I, pp. $107-131$.

Dalton Conroy. R., Hölscher C., Spiers H. J. (20I5). Navigating Complex Buildings: Cognition, Neuroscience and Architectural Design. In Studying Visual and Spatial Reasoning for Design Creativity, pp. 3-22. Netherlands: Springer.

Empler T. (1997). Progettare il comfort urbano e d'interni: Guida ad una progettazione plurisensoriale. Rimini: Maggioli.

Gibson J. J. (1979). The ecological approach to visual perception. Boston: Houghton Mifflin Company.

Golledge R. G., Stimson R. J. (1997). Spatial behavior: a geographic perspective. New York: Guilford Press. 
Helg F. (1979). II museo di Sant'Agostino nel centro storico di Genova. In Casabella, n. 443, pp. 28-33.

Hill K. (1998). The Psychology of Lost. In K. Hill (a cura di). Lost Person Behavior, pp. I - I 5. Ottawa, Canada: National SAR Secretariat.

Hillier B. (2007). Space Is the Machine: A Configurational Theory of Architecture. London: Space Syntax.

Holl S. (2004). Parallax. Architettura e percezione. Milano: Postmedia Srl.

Hölscher C., Brösamle M.,Vrachliotis G. (20I2). Challenges in multilevel wayfinding: a case study with the space syntax technique. In Environment and planning B: Planning and Design, 39, n. I, pp. 63-82.

Lynch K. (1960). The image of the city. Cambridge, Mass: MIT Press.

Mallgrave H. F. (2013). Architecture and Embodiment. The implication of the new sciences and Humaties for Design. London: Routlgedge.

Nothegger C., Winter S., Raubal M. (2004). Selection of Salient Features for Route Directions. In Spatial Cognition and Computation, n. 4, pp. I13-136.

Papadopoulos K., Koustriava E., Barouti M. (2017). Cognitive Maps of Individuals with Blindness for Familiar and Unfamiliar Spaces: Construction through Audio-Tactile Maps and Walked Experience. In Computers in Human Behavior, n. 75, pp. 376-384.

Robinson S., Pallasmaa J. (20I5). Mind in architecture: Neuroscience, embodiment, and the future of design. Cambridge Mass.: MIT Press.

Spesso M., Porcile G. L. (2019). Da Zevi a Labò, Albini e Marcenaro: Musei a Genova 1948-1962: intersezioni tra razionalismo e organicismo. Genova: University Press.

Weisman J. (198I). Evaluating Architectural Legibility: Way-Finding in the Built Environment. In Environment and Behavior, I3, $\mathrm{n}$. 2, pp. $189-204$.

\section{Authors}

Cristina Càndito, Università di Genova, cristina.candito@unige.it

Alessandro Meloni, Università di Genova, arch.melonialessandro@gmail.com

To cite this chapter. Càndito Cristina, Meloni Alessandro (2021). II contributo della rappresentazione alla percezione dell'architettura. Orientamento, connessioni spaziali e accessibilita/The contribution of representation to the perception of architecture. Orientation, spatial connections and accessibility. In Arena A., Arena M., Mediati D., Raffa P. (a cura di). Connettere. Un disegno per annodare e tessere. Linguaggi Distanze Tecnologie. Atti del $42^{\circ}$ Convegno Internazionale dei Docenti delle Discipline della Rappresentazione/Connecting. Drawing for weaving relationship. Languages Distances Technologies. Proceedings of the $42^{\text {th }}$ International Conference of Representation Disciplines Teachers. Milano: FrancoAngeli, pp. I 4 I 5 - I 434 . 